\title{
Places as Assemblages: Paradigm Shift or Fashionable Nonsense?
}

\author{
By Milica Muminovic*
}

Ever since Heidegger's definitions of being and dwelling, and further interpretations of those definitions in the work of Christian Norberg-Schulz, the theory of place has been developing as a category of phenomenology. The notion of being is considered unseparated from building and thus fundamental for the definition of place. In the past decade, the phenomenological tradition in place theory has been challenged, largely inspired by the work of Gilles Deleuze. Deleuze's opus is particularly interesting because of the introduction of a new kind of realism, positioned between phenomenology and materialism, where being is replaced with becoming. In nonphilosophical circles, that emerging epistemology and ontology is usually referred to as assemblage theory. For some scholars, assemblage theory is a problematic opus; for others it represents potential for the further development of existing theories. Despite being introduced in various disciplines, most of the research in this field terminates with assemblage as a metaphor, while losing all the complexity of Deleuze's ontology. In place theory, assemblage appears in the work of Kim Dovey and his book Becoming Places (2010). This work represents a systematic effort to introduce new ontology into place theory and raises questions of the impact this ontology can have for the creation of a new approach to place. Thus we might ask: is this another example of fashionable nonsense that architects seem to embrace? Or are we hypothetically dealing with a different view of place? This paper aims to discuss the ways in which assemblage theory might be affecting common notions we have about place. The analysis focuses on the application of philosophical concepts to place theory. Thus, the analysis is framed within the main philosophical concepts introduced in place theory (Heidegger and Deleuze) and place theory directly referencing those two philosophical approaches (Norberg-Schulz and Dovey). Comparison is based on the fundamental aspects of place, concerning the definition of place and its relationship with time.

Keywords: Assemblages, Phenomenology, Place, Theory

\section{Introduction}

Assemblage theory is an emerging discourse that predominantly derives from Gilles Deleuze's philosophy. It is referred to as "comprehensive theory", 1 neither a theory nor a philosophy as understood in the traditional

\footnotetext{
* Assistant Professor, University of Canberra, Australia.

${ }^{1}$ Manuel Delanda, A New Philosophy of Society- Assemblage Theory and Social Complexity. (London- New York: Continuum, 2006), 5.
} 
classification. ${ }^{2}$ In the broadest sense, it can be defined as the application of Deleuze's philosophical concepts to various theories. During that process, universal philosophical concepts are contextualized and tested. The applications range from theoretical to methodological and even artistic. Although inspired by Deleuze's philosophy, assemblage theory does not entirely follow all the concepts deriving from that philosophy. This field of different ideas developing or referring to Deleuze's philosophy has not yet reached coherence. In some cases, it is far from the original ideas presented in Deleuze's writing. The fact that these concepts are applied to various fields contributes to the incoherent discourse around the term assemblages. Even the translation from French to English is problematic. John Philips argues that there is a misinterpretation of the concept of agacement which is translated into English as assemblage. ${ }^{3}$

Regardless of being incoherent at the level of philosophy, assemblage theory becomes useful when it is mobilized with other existing theories or concepts. ${ }^{4}$ For example, there are three levels of application of assemblage theory to critical urbanism and political economy: empirical (explaining actual assemblages), methodological and ontological. ${ }^{5,6}$ All three are generating new ideas within existing theories without abolishing or replacing them.

In architecture, Deleuze's influence was seen through a wide range of interpretations of the concept of the fold, introduced in his book The Fold: Leibniz and the Baroque (1988), and concepts of striated and smooth spaces described in the final chapter of The Thousand Plateus (1987). The work presented in the latter book stimulates subjectivity, creativity and new ideas in architecture. $^{7}$

Deleuze's philosophy does not generate clear messages, which means the language is subject to manipulation. For example, the introduction of the word assemblages to any theory raises questions of validity and rigor of theory, already seen in various postmodernist approaches. Examining the impact of postmodernistic thought in humanities and social sciences, Sokal and Bricmont have identified four main problematic fields: (1) fascination with obscure discourse; (2) epistemic relativism and skepticism with modern science; (3) interest in subjective beliefs; and (4) emphasis on discourse as opposed to facts. ${ }^{8}$ All these aspects can also be found in various discussions of applications of assemblage theory in architecture. The work of Deleuze and

\footnotetext{
${ }^{2}$ Branko Mitrovic, Philosophy for Architects (New York: Princeton Architectural Press, 2011), 168.

3 John Phillips, “Agencement/Assemblage.” Theory, Culture \& Society 23, 2-3 (2006): 108-09.

${ }^{4}$ Neil Brenner, David J. Madden, and David Wachsmuth, "Assemblage urbanism and the challenges of critical urban theory." City. 15, 2, (2011): 230.

${ }^{5}$ Brenner, Madden and Wachsmuth, "Assemblage urbanism," 230-1.

${ }^{6}$ Colin McFarlane, “Assemblage and Critical Urban Praxis: Part One.” City, 15, 2, (2011): 204-24.

${ }^{7}$ Mitrovic, Philosophy for Architects, 168.

${ }^{8}$ Alan Sokal and Jean Bricmont, Fashionable Nonsense. Postmodern Intellectuals' Abuse of Science (New York: Picador, 1997), 183.
} 
assemblage theory is often used as "nonphilosophical understanding of philosophy", particularly in art, architecture, design and urbanism. ${ }^{9}$

However, the application of philosophical concepts has a long tradition in architectural theory. Questions on aesthetics, proportions and types are closely related to the development of philosophical and scientific discoveries that determine architectural theories. ${ }^{10}$ One such direct application of philosophy to theory was place theory in architecture. In his writings, Christian NorbergSchulz developed a theory on place based on the application of phenomenology in architecture. The work, presented in Intentions in Architecture (1963), Genius Loci: Towards a Phenomenology in Architecture (1974) and Concept of Dwelling (1993), are largely derived from application of Heidegger's Building Dwelling Thinking to architectural theory. Place theory is based on the relationships to built environment within the concept of dwelling.

Recently, the application of assemblage theory has begun to emerge in place theory. Kim Dovey introduces places as assemblages and aims to contribute to a new understanding of place. This new approach aims to distance place from dwelling and rootedness, and create a new, dynamic definition. However, the vague definition of assemblage and places as assemblages has the potential to be seen as mere application of a new, fashionable discourse to theory without changing the fundamental definitions of place. It is necessary to examine the potential contribution of assemblage theory and confirm if new definitions, methodologies and empirical applications are more than just a new use of discourse.

Thus, this paper examines the possibilities for developing new concepts that assemblage theory offers within place theory. The questions raised in this paper are: To what extent can assemblage theory contribute to new concepts in place theory? Which concepts offer a new understanding of place? Are we dealing with another fascination with discourse offered through assemblage?

\section{Approach}

To answer the questions proposed in this paper, the analysis focuses on the application of philosophical concepts to place theory. Thus, the analysis is framed within the transition of broad philosophical concepts to concrete theoretical approaches to place. Authors who define place with direct reference to philosophy were selected: Christian Norberg-Schulz (phenomenology and its introduction to place theory) and Kim Dovey (assemblage theory and its introduction to place theory). This paper examines the differences between those two approaches.

The definition of place based on the Heideggerian approach has a long tradition, and was introduced into architecture by Norberg-Schulz. In contrast, the application of assemblage theory into place theory is in its infancy. In his

\footnotetext{
${ }^{9}$ See for example: John Rajchman, The Deleuze Connections (Cambridge Massachusetts: The MIT Press, 2000).

${ }^{10}$ See for example: Mitrovic, Philosophy for Architects.
} 
book Becoming Places (2010), Kim Dovey defines place as assemblage and begins to formulate a new approach to place theory. Since both theories directly build their concepts from philosophy, the comparison of the two approaches will follow the flow of application of philosophical concepts to theory. The aim of this paper is not to compare the philosophy of Heidegger and Deleuze, but to map the differences between the philosophical concepts that are introduced into theory. Thus, the comparison is conducted at two parallel levels: philosophical (Heidegger and Deleuze) and theoretical (Norberg-Schulz and Dovey).

The hypothesis is that differences between the concepts in phenomenology and assemblage theory will reveal the potential for a new definition of place and the ways in which that will affect current place theory.

The analysis focuses on fundamental definitions of place. Thus, this paper compares the two approaches to the definition of place and its relationship to durability as fundamental aspects of place theory. Comparison is structured around definitions of place (place as phenomenon and assemblage) and time (essence and multiplicity; persistence and change). The analysis begins with the comparison of the two philosophical approaches by briefly introducing the work of Heidegger and Deleuze in relation to being and place. Secondly, the definitions of place are compared in relation to essence and time. The paper concludes with discussion on the main differences between the two approaches and their effects on current theory.

\section{Definition of Place}

\section{Phenomenology}

Deriving from the Greek word phainomenon, phenomenology represents a discipline that studies and describes appearances. ${ }^{11}$ According to this approach, it is impossible to obtain a presupposition-less understanding of the world. Heidegger gives the most suggestive and sustained definition of place in the past century that comes from phenomenology. ${ }^{12}$ This definition is derived from Dasein's (human being) authentic being-in-the-world. Heidegger accomplishes the definition of place although he rarely addresses place in itself as a topic. ${ }^{13}$ Temporality is essential in the definition of Dasein, which is the horizon of Being. ${ }^{14}$ Heidegger illuminates place through dwelling, nearness and the event of Appropriation ${ }^{15}$ and sets the space for definition of place through being:

"The [place] is not already there before the bridge is. Before the bridge stands, there are of course many spots along the stream that can be occupied by something. One of them proves to be a [place], and does so because of the

\footnotetext{
${ }^{11}$ Mitrovic, Philosophy for Architects, 121.

${ }^{12}$ Edward Casey S., The Fate of Place-A Philosophical History (Berkeley/Los

Angeles/London: University of California Press, 1997), 284.

${ }^{13}$ Ibid.

${ }^{14}$ Ibid, 245

${ }^{15}$ Ibid, 335 .
} 
bridge. Thus the bridge does not come first to a [place] to stand in it; rather the [place] comes into existence only by virtue of the bridge". ${ }^{16}$

This definition of place links being and the way people are dwelling with the processes of building. Throughout the act of building and experiencing, the location becomes place. In its natural state, the location is still not a place. The place is defined as a phenomenon, and can exist only through experiences. For Heidegger, all entities are phenomena: "to let that which shows itself be seen from itself in the very way in which it shows itself from itself". ${ }^{17}$ This represents the basic notion of phenomenology, as Large explains: "there is not a subject and object separate from one another, which then, through some kind of unknowable process, have to become linked or attached. Rather, they are already intertwined in our direct experience of the world". ${ }^{18}$ Considering place as any other thing, Casey explains, "place is not something we come across as something we are simply in". ${ }^{19}$ Place appears in "conjoint" action between people and physical reality through "intervention". ${ }^{20}$ A place, therefore, exists only in the interaction between people and location. Place is a phenomenon. Place is not about the built environment but how people are dwelling in that environment. Any location has the potential to become a place, and any place has the potential to become mere location.

Because of the link between place, dwelling and being, time becomes an important factor in the definition of place. This definition distances place from the physical aspects of the outside world. The experience and meanings of our own existence are intertwined within the process of constant creation of place. People are not simply users of a place but are actively involved in its creation through the act of building and experiencing. The built environment is a mode by which people create places and fulfil their need for a meaningful existence.

\section{Theory}

Norberg-Schulz adopts Heidegger's approach in which being is spatial, and further develops this concept as existential space. ${ }^{21}$ In defining place as part of people's existence, identity becomes a fundamental element in the definition. ${ }^{22}$ Identity refers to the quality and uniqueness of a certain location. It comprises both tangible and intangible characteristics that distinguish its authenticity in relation to other places. The identity reveals the essence of a place that emerges between people and location. Location comprises built

\footnotetext{
${ }^{16}$ Martin Heidegger, Poetry, Language, Thought, trans. Albert Hofstadter (New York: Harper and Row, 1971),151-2.

${ }^{17}$ Martin Heidegger, Being and Time, trans. John Maquarrie and Edward Robinson (Oxford: Basil Blackwell, 1962), 58.

${ }^{18}$ William Large, Heidegger's Being and Time (Edinburgh: Edinburgh University Press, 2008), 5.

${ }^{19}$ Casey, The fate of place, 250.

${ }^{20}$ Ibid.

${ }^{21}$ Christian Norberg-Schulz. Existence, space and architecture (London: Studio Vista Limited, 1971), 27.

${ }^{22}$ Christian Norberg-Schulz. Genius loci, Towards a phenomenology of architecture (New York: Rizzoli International Publications, 1980), 10.
} 
environment and activities and existential space defines the meanings emerging from the interaction between people and location..$^{23}$ Tangible elements of the identity of a place, its physical setting and activities are palpable and inherent elements that conceive ground for its creation. Intangible elements of identity of a place establish themselves through people's experiences. Those experiences, while based on the tangible elements of a place, do not necessary depend on it. The meanings of place may be situated and connected with its physical elements and associated activities, but they are not their property; they are, rather, the property of human intentions and experiences. "Meanings can change and be transferred from one set of objects to another, and they posses their own qualities of complexity, obscurity, clarity or whatever." ${ }^{24}$ As such, they involve both individual and cultural variations, “... which reflect particular interests, experiences and viewpoints" ${ }^{25}$ However, meanings related to a place are not entirely divorced from the built environment, or human-made. Such meanings have to be based on a concrete physical setting, that is, in the outside world. ${ }^{26}$

Norberg-Schultz analyses place using categories such as space and character, or tangible and intangible elements. ${ }^{27}$ Space is related to the physical setting of a place and character illuminates atmosphere, which appears in relation to people and space. Places are determined through centre and enclosure, defined through personal, meaningful events. ${ }^{28}$

\section{Place as Assemblage}

Deleuze positions his work as a new kind of materialism. His philosophy is distinguished from dialectical materialism by being positioned between phenomenology and materialism. ${ }^{29}$ Being is univocal, and Deleuze proposes in his "experimental style" a number of paired concepts to determine being as an "interval or nominal interface". ${ }^{30}$ Badiou summarizes the following pairs as most important for the definition of being: virtual and actual, time and truth, chance and eternal return, the fold and the outside. ${ }^{31}$ Although not completely distancing the definitions of being from phenomenological aspects, Deleuze shifts the focus of exploration towards processes in the material world.

The second important element of the definition of being in Deleuze's philosophy is related to its dynamics. Deleuze describes entities in the process of becoming, as opposed to the notions of being. ${ }^{32}$ Deleuzian ontology, as

\footnotetext{
${ }^{23}$ Edward Relph. Place and placelessness (London: Pion Limited, 1986), 47.

${ }^{24}$ Ibid.

25 Ibid.

${ }^{26}$ Norberg-Schulz. Genius loci, 170.

${ }^{27}$ Ibid, 11 .

${ }^{28}$ Norberg-Schulz. Existence, 19.

${ }^{29}$ Gilles Deleuze. Difference and Repetition, trans. Paul Patton (New York: Columbia University Press, 1994), 222.

${ }^{30}$ Alain Badiou, Deleuze, The Clamor of Being, trans. Louise Burchill (Minneapolis:

University of Minnesota Press, 2000), 28.

${ }^{31}$ Ibid, 29.

${ }^{32}$ Deleuze. Difference and Repetition, 41.
} 
Delanda explains, defines a “...universe where individual beings do exist but only as the outcome of becomings, that is, of irreversible processes of individualization". ${ }^{33}$ To describe the process of becoming, Delanda uses the example of water at $0^{\circ} \mathrm{C}$. At that point, water is neither liquid nor solid, it is purely in the process of becoming. The state of becoming could be further explained in the words of Deleuze: "...already-there that is at the same time not-yet-here, a simultaneous too late and too-early, a something that is both going to happen and has just happened". ${ }^{34}$ This process of becoming does not mean that all entities are in constant dynamic change and flux, but it aims to give a broader understanding of change over time.

In Deleuze's philosophy, place and being are not necessarily linked. The definition of place is represented as the definition of any entity using the concept of assemblage. Thus, place in this context is defined when the concept of assemblage is introduced into already exiting place theory.

\section{Theory}

Kim Dovey depicts place as territorialized assemblage, as a dynamic rhizomatic structure of people and the environment, which is both material and experiential. Assemblages (and thus places as well) are "wholes whose properties emerge from the interaction between parts". ${ }^{35}$ The emphasis is on the relationships between the elements that constitute the assemblage rather than on the elements themselves. ${ }^{36}$ Thus, assemblage is not a simple sum of the elements, nor can it be reduced to its parts.

The shift from predominantly phenomenological to a new kind of materialism built on Deleuze's positioning between materialism and phenomenology ${ }^{37}$ represents an important element that reintroduces the built environment as a significant factor in the definition of place. Defining places as assemblages has a direct implication for understanding the place reduced to a subjective experience-phenomenon. Namely, in assemblage theory, there is an emphasis on the material world, which is between phenomena and noumena. ${ }^{38}$ Thus, place and its identity appear in the interaction of experience and the material setting of the place. As Dovey explains, the senses or meanings of a place are neither found within the material urban form nor are they simply added to it; rather, they are integral to assemblage. ${ }^{39}$ Meanings of place are not simply attached to places; they are already part of it. They are always

\footnotetext{
${ }^{33}$ Manuel Delanda, Intensive Science and Virtual Philosophy (London and New York: Continuum, 2002), 84.

${ }^{34}$ Gilles Deleuze and Felix Guattari, A Thousand Plateaus Capitalism and Schizophrenia, trans. Brian Massumi (Minneapolis: University of Minnesota Press, 1987), 262.

${ }^{35}$ Manuel Delanda, A New Philosophy of Society-Assemblage Theory and Social Complexity (London- New York: Continuum, 2006), 5.

${ }^{36}$ Ibid, 18.

${ }^{37}$ Deleuze. Difference and Repetition, 222.

${ }^{38}$ Manuel Delanda, "Deleuze, Diagrams, and the Genesis of Form," Amerikanstudien/American Studies, 45, (2000): 36.

${ }^{39}$ Kim Dovey, Becoming Places, Urbanism/Architecture/Identity/Power (London and New York: Routledge, 2010), 17.
} 
interacting with elements that comprise that place. The quest for a sense of place is a paradox. As Dovey explains, "language can name this sense but is powerless to define it". ${ }^{40}$ Sensation operates before cognition and meaning. The encounter with a song, painting, poem or place is experienced before analysis can turn it into a proposition. ${ }^{41}$

\section{Place and Time in Theory}

\section{Essence}

Essence is not a concept exclusively developed by Heidegger. Acceptance of essence basically means that any entity would have "a quality, character or nature intrinsic to their being, which distinguishes them from all other things". ${ }^{42}$ Essences are considered to be universal, abstract, invariant, eternal, ideal and belonging to the realm of transcendental. Essence determines what the thing is, and a change in essence will define the point at which that thing stops to exist or transforms into something else. ${ }^{43,44}$

Norberg-Schultz uses the concept of eternal essence to describe a place and ways of building and maintaining the qualities of a location that has become a place. Norberg-Schulz adopts the concept of genius for the description of place and essence and develops it into genius loci. This concept derives from the Roman belief that all beings (even Gods) have their genius, their guardian spirit, which determines their character and their identity. He further explains that "this spirit gives life to people and places, accompanies them from birth to death, and determines their character and essence". ${ }^{45}$ Referencing Romans and their rituals in founding cities, Norberg-Schulz adopts the transcendental nature of the concept. This continuity of the spirit of place refers not only to the built environment, but also to the atmosphere that could be found in the natural characteristics of the location before the act of building. Atmosphere is preserved within the form or character of the built environment and defines the morphological characteristics of a place. ${ }^{46}$ Continuity can be found within various scales in the built environment, ranging from architectural detail to the city-level scale. Typological continuities for Norberg-Schulz represent one of the most important qualities of place, which produces the "necessary stabilitas loci". ${ }^{47}$

\footnotetext{
${ }^{40}$ Ibid, 25.

41 Ibid

${ }^{42}$ David Tabachnick, "Heidegger's Essentialist Responses to the Challenge of Technology," Canadian Journal of Political Science 40, no. 2 (2007): 489.

${ }^{43}$ Christopher. H. Conn, Locke on essence and identity (Dordrecht: Kluwer Academic Publishers, 2003), 8.

${ }^{44}$ Frederick. C. Doepke, The Kinds of Things, A Theory of Personal Identity Based on Transcendental Argument (Chicago: Carus Publishing Company, 1996), 148.

${ }^{45}$ Norberg-Schulz. Genius loci, 18.

${ }^{46}$ Christian Norberg-Schulz, Architecture: Presence, Language, Place, Trans. Shugaar, A. (Milano: Skira Editore, 2000), 160.

${ }^{47}$ Ibid, 133.
} 
In phenomenology, durability of a place is determined thorough its essential characteristics. Essences are eternal and define a place's identity. The essence is a necessary element of a place and exists from its birth to its death. Thus, the maintenance of place identity refers to essential qualities that should be preserved in its built environment.

\section{Multiplicity}

Instead of essence, Deleuze uses the term real essences. The concept introduced by Deleuze recognizes the importance of essence, but presents a different understanding of them. These real essences refer to particular beings, which are "mobile and immanent in material things, real and material, concrete and subject to variation". ${ }^{48}$ The essence as an archetype, a static concept, is replaced with a dynamic concept of individual beings in which the morphogenetic process becomes an important part of the essence. ${ }^{49}$ As Delanda explains, essence is replaced with the concept of multiplicity, which is defined through becoming, rather than being. In Deleuze's flat ontology, there are singular or individual essences that are defined through the morphogenetic characteristics of the entity. ${ }^{50}$ The common notions or the similarities between entities are determined through similar morphogenetic processes. ${ }^{51}$ Those real essences could be described as productive powers that are real and related to particular beings and their histories..$^{52}$

The main characteristics of particular essences or multiplicities are described in relation to time and change. Multiplicities are dynamic concepts that define an individual rather than type and are progressively changing over time..$^{53}$

Multiplicities have an important role in determining identity, change and persistence. They are describing the "structure of spaces of possibilities" as part of morphogenetic processes. ${ }^{54}$ Thus, multiplicities are not given all at once; they are possibilities, in which every entity is a product of its own history. They reveal themselves over time and through concrete historical development of an entity. Essences are clear, distinctive and eternal while multiplicities determine "long-term tendencies, [and] structure the possibilities which make up state space". ${ }^{55}$ Essences guide the processes of change. ${ }^{56}$

The application of multiplicity in the definition of place has implications related to maintenance and durability of place. Despite the commonly

\footnotetext{
${ }^{48}$ Bruce Baugh, "Real Essences without Essentialism," in Deleuze and Philosophy, ed. Constantine V. Boundas (Edinburgh: Edinburgh University Press, 2006), 31.

${ }^{49}$ Delanda, Intensive Science and Virtual Philosophy, 9-10.

${ }^{50}$ Ibid.

${ }^{51}$ Baugh, "Real Essences without Essentialism," 37.

52 Ibid, 39.

${ }^{53}$ Gilles Deleuze, Bergsonism, trans. H. Tomlinson and B. Habberjam (New York: Zone Books, 1991), 40-2.

${ }^{54}$ Delanda, Intensive Science and Virtual Philosophy, 10.

${ }^{55}$ Ibid, 16.

${ }^{56}$ Manuel Delanda, "Space: Extensive and Intensive, Actual and Virtual," in Deleuze and Space, ed. I. Buchanan and G. Lambert (Edinburgh: Edinburgh University Press, 2005), 83.
} 
recognized idea that genius loci, spirit or identity of place are static phenomena that define the essence of place, Dovey argues that identity is an integral element of place assemblage and, as such, is always in the process of becoming, or change. This approach represents a shift towards place, in terms of spatiality and sociality. The definition of genius loci as stabilitas loci is reduction and it ignores social constructions of place identity. ${ }^{57}$ In that sense, the identity of place does not represent the number of characteristics, which defines its uniqueness (essence). Rather, it represents processes that determine its individualization. That implies possibilities for different structures of the built environment to form the same identity (defined through multiplicity). Furthermore, it has direct implication in the persistence of a place within the change of its built environment.

For Dovey (2010), identifying space with "freedom" and "movement", in contrast to place with "stability" and "rootedness", is a serious mistake. Place should be conceived as an assembled mix. ${ }^{58}$ According to this view, the distinction of place and space lies in intensity, which is in relation to people and physical settings, conceived as assemblages. The relationship between elements of an assemblage define place. Thus “...what distinguishes place from space is that place has an intensity that connects sociality to spatiality in everyday life". ${ }^{59}$

\section{Persistence}

Following Heidegger's definition, place is a phenomenon that appears as the product of being and dwelling. As a result, the experience of location becomes very important for the definition of place, as Tuan emphasizes: "...the feel of a place is registered in one's muscles and bones". ${ }^{60}$ Thus, time represents an important element for creation and maintenance of place. The location could become a place for people who spend a long time in knowing and experiencing it (insiders) while for others who have only limited experience (outsiders), it could still remain just a location. ${ }^{61}$ Thus, the place comprises the outside world (the built environment and activities) but also personal and shared experiences of that world producing meanings and feelings of attachment. The built environment represents only one aspect of a place, the precondition for place to emerge. Place appears through interaction between subject and location; it takes time for place to emerge. To obtain experience and meaning, to feel the sense of place, one needs to spend some time knowing a place. ${ }^{62}$

Another important relationship between time and place is found within its past. For a place to evoke particular meanings and experiences, it has to have traces from the past, assimilating different temporalities in itself and thus

\footnotetext{
${ }_{58}^{57}$ Dovey, Becoming Places, 5.

${ }^{58}$ Ibid, 23.

${ }^{59}$ Ibid, 3 .

${ }^{60} \mathrm{Yi}$-Fu Tuan, Space and Place-The Perspective of Experience (Minneapolis: The University of Minnesota Press, 1977), 184.

${ }^{61}$ Relph, Place and Placelessness, 49.

${ }^{62}$ Tuan, Space and Place, 186.
} 
creating a clear connection with its past. ${ }^{63}$ One important aspect of the built environment lies in the passage of time, materialized in palimpsest, what Lynch defines as "temporal collage". ${ }^{64}$ Norberg-Schulz emphasizes the importance of continuity of the character of location which is built on the persistence of a character of the landscape, before the act of building and dwelling. ${ }^{65}$

For a place to maintain its character or be persistent over time, it must maintain its essence. This can be through traces from the past recognizable in the built environment or within typological characteristics. Thus, in the process of place making, architects and planners should recognize essential characteristics of the built environment, to preserve and conserve them.

\section{Change}

The definition of place as assemblage does not imply that it is in constant processes of formation and change. Those processes are not linear, because multiplicity can have a number of possible states of becoming, defined through two dimensions (Figure 1). One comprises various roles that components of assemblage may play, creating different mixtures of material role at one extreme and expressive role at the other. ${ }^{66}$ The material role of elements of assemblage is the way those elements occupy space; it defines only their physical characteristics. Expressive role defines their qualitative characteristics, their function in the assemblage as agents. At the level of place, the built environment will take the material role and meanings will take the expressive. All assemblages are a mixture of different levels of material and expressive roles.

The second dimension defines processes in which these components become involved: on the one side stabilized, or increasingly homogenized (territorialization), and on the other side increasing heterogenization called deterritorialization. Different assemblages can have various levels of material expressive dimension or stabilized and change-territorialized and deterritorialized characteristics. ${ }^{67}$ As Delanda explains, "the identity of any assemblage at any level of scale is always the product of a process (territorialization, and in some cases coding) and it is always precarious, since other processes (deterritorialization and decoding) can destabilize it". ${ }^{68}$ Various levels of territorialization and expressiveness may appear at different points in time through individualization.

\footnotetext{
${ }^{63}$ Kevin Lynch, What time is this place? (Massachusetts and London: The MIT Press Cambridge, 1972), 1.

${ }^{64}$ Ibid, 173.

${ }^{65}$ Norberg-Schulz, Architecture: Presence, Language, Place, 160.

${ }^{66}$ Delanda, A New Philosophy of Society, 12.

${ }^{67}$ Ibid.

${ }^{68}$ Ibid, 28.
} 
Figure 1. Schematic Representation of the Multiplicity over Time (This figure illustrates one possible development of an entity, staring from a dominantly expressive role of its extensive qualities and, at the same time, having blurred boundaries and heterogeneity. Further in time, the entity is showing a more territorialized state with a dominantly material role. This can be explained at the example of place identity being highly linked with particular buildings and having very clear boundaries. At the same time, the process of demolishing the buildings might start and identity will shift into a more expressive state with less clear boundaries.)

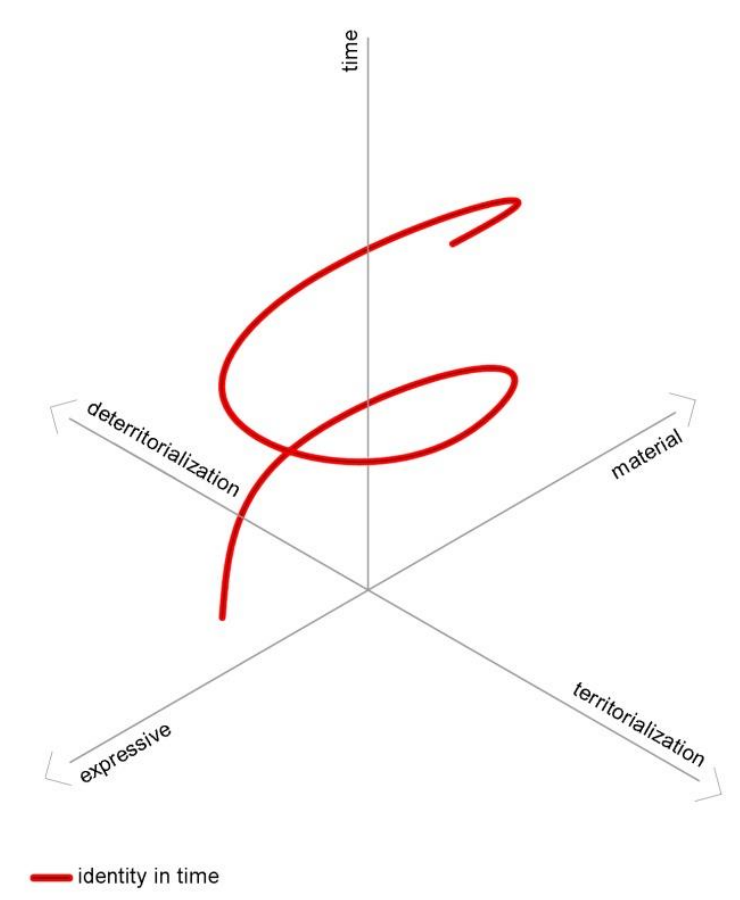

\section{Conclusions}

The comparison of Heidegger's and Deleuze's approaches to place theory has revealed differences and similarities in definitions of place. The key difference emerges from the definition of being and its relationship with dwelling. The being in the Deleuzian approach is defined through becoming that implies processes, and it is univocal. There is no division between the outside world and the subject that is connected to that world through place. Thus, analysis at the level of theory in comparing Norberg-Schultz with Dovey exhibits differences in the definition of place. Place is defined as assemblage of various elements that constitute location. The meanings and individual experiences are part of the place assemblage. The individual being does not emerge in the relationship with the built environment and dwelling. That does not mean that place is not a phenomenon, however, as the being becomes part of the place assemblage. In that sense, it could be argued that this approach 
represents a shift towards the built environment and existential space is not the focal point of the definition of place (Figure 2).

Despite this important difference, it is a generalization to say that we have come to a different view from Heidegger. The question of whether a place would exist without people or their experiences brings us back to phenomenology. From this brief analysis, we can argue that at a fundamental level, Deleuzian philosophy is not offering new ideas and definitions. Place is still a phenomenon.

However, there are some important contributions from assemblage theory applied to place theory, particularly at the fine descriptions of place. One potential contribution is in relation to change of a built environment and the introduction of the material and expressive role of elements that constitute place. The fact that place changes from material to expressive, having various mixes over time, is important for defining the types-essences. This implies that places should be considered as unique and within historical processes, in order to understand their shifts from material to expressive roles and levels of importance of tangible or intangible aspects. This approach potentially shifts understanding of place away from typological analysis. Since place can obtain a predominantly expressive role, built environment and typological differences have less impact on a place's identity. Current theory assumes that to be a place, location needs to be in the state of defined territorialsation and their physical setting should have a predominantly material role. Assemblage theory offers understanding of place through its development, giving a much broader image of place that can have phases of territorialsation-deterritorialsation and material-expressive roles.

The largest difference and thus the possibility for further development of place theory is found in the definition of essence. Essence is not defined as a static eternal concept, but rather as a dynamic, individual component formed over time. This definition of essence has important consequences in the methodology and design of places. Places as assemblages are shifting from an essentialist approach to particular essences. Particular essences are determined through morphological processes. Therefore, each location is unique. Furthermore, Delanda's interpretation of essence (replaced with multiplicity) reveals a more important implication. The built environment of a place is dynamic and does not require a search for eternal (essential) elements that we need to preserve.

A review of material and expressive roles and essence has shown that there is a lack of consideration of this concept in place theory, with the possibility for further exploration and raising the questions: If essence is changeable (multiplicity), how can we design for persistence of places? How can we capture/represent/conceive this changeable essence?

Multiplicity offers the greatest possibility for development of a new theory in architecture. This concept, although still not interpreted in architectural theory, aims to understand places as dynamic structures. Place is shifting away from the rootedness, stability, experience and existential space defined during 
the last century. This point of view is closer to a new way of life, where being is accelerated, experiencing a place in new ways.

Figure 2. Comparative Scheme of Place Definitions (Phenomenology on the Left and Assemblage on the Right)
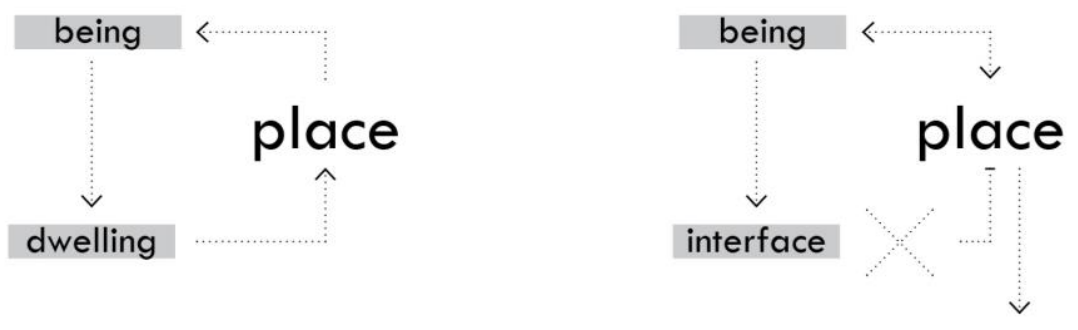

assemblage

Based on the analysis presented in this paper, we conclude that assemblage theory does offer a different approach to place theory in relationship to phenomenology. This is not a new approach that will abolish the understanding of place as a phenomenon emerging from the interaction between people and the built environment. The contribution seems not to be at the ontological level or at the level of defining places as assemblages, since that states almost the obvious: places are composed of parts. The major contribution of places as assemblages is at the practical application of theory to analysis and design.

\section{Bibliography}

Badiou, Alain. Deleuze, The Clamor of Being. Translated by Louise Burchill. Minneapolis: University of Minnesota Press, 2000.

Baugh, Bruce. "Real Essences without Essentialism." In Deleuze and Philosophy, edited by Constantine V. Boundas, 31-42. Edinburgh: Edinburgh University Press, 2006.

Brenner, Neil, Madden, David J., and Wachsmuth, David. "Assemblage urbanism and the challenges of critical urban theory." City. 15, 2, (2011): 225-40.

Casey, Edward. S. The Fate of Place-A Philosophical History. Berkeley/Los Angeles/London: University of California Press, 1997.

Conn, Christopher. H., Locke on essence and identity. Dordrecht: Kluwer Academic Publishers, 2003.

Delanda, Manuel. "Deleuze, Diagrams, and the Genesis of Form". Amerikanstudien/American Studies, 45, 1, (2000), 33-41.

Delanda, Manuel. Intensive Science and Virtual Philosophy. London and New York: Continuum, 2002.

Delanda, Manuel. "Space: Extensive and Intensive, Actual and Virtual." In Deleuze and Space, edited by I. Buchanan and G. Lambert, 80-88. Edinburgh: Edinburgh University Press, 2005. 
Delanda, Manuel. A New Philosophy of Society-Assemblage Theory and Social Complexity. London- New York: Continuum, 2006.

Deleuze, Gilles and Guattari, Felix. A Thousand Plateaus Capitalism and Schizophrenia. Translated by Brian Massumi. Minneapolis: University of Minnesota Press, 1987.

Deleuze, Gilles. Bergsonism. Translated by H. Tomlinson and B. Habberjam. New York: Zone Books, 1991.

Deleuze, Gilles. Difference and Repetition. Translated by Paul Patton. New York: Columbia University Press, 1994.

Doepke, Frederick. C., The Kinds of Things, A Theory of Personal Identity Based on Transcendental Argument. Chicago: Carus Publishing Company, 1996.

Dovey, Kim. Becoming Places, Urbanism/Architecture/Identity/Power. London and New York: Routledge, 2010.

Heidegger, Martin. Being and Time. Translated by John Maquarrie and Edward Robinson. Oxford: Basil Blackwell, 1962.

Heidegger, Martin. Poetry, Language, Thought. Translated by Albert Hofstadter. New York: Harper and Row, 1971.

Large, William. Heidegger's Being and Time. Edinburgh: Edinburgh University Press, 2008.

Lynch, Kevin. What time is this place?. Massachusetts and London: The MIT Press Cambridge, 1972.

McFarlane, Colin. "Assemblage and Critical Urban Praxis: Part One.” City, 15, 2, (2011): 204-24.

Mitrovic, Branko. Philosophy for Architects. New York: Princeton Architectural Press, 2011.

Norberg-Schulz, Christian. Existence, space and architecture. London: Studio Vista Limited, 1971.

Norberg-Schulz, Christian. Genius loci towards a phenomenology of architecture. New York: Rizzoli International Publications, 1980.

Norberg-Schulz, Christian. Architecture: Presence, Language, Place. Translated by Shugaar, A. Milano: Skira Editore, 2000.

Phillips, John. "Agencement/Assemblage.” Theory, Culture \& Society 23, 2-3 (2006): 108-09.

Rajchman, John. The Deleuze Connections. Cambridge Massachusetts: The MIT Press, 2000.

Relph, Edward. Place and placelessness. London: Pion Limited, 1986.

Sokal, Alan and Bricmont, Jean. Fashionable Nonsense. Postmodern Intellectuals' Abuse of Science. New York: Picador, 1997.

Tabachnick, David E. "Heidegger's Essentialist Responses to the Challenge of Technology." Canadian Journal of Political Science 40, no. 2 (2007): 487-505.

Tuan, Yi-Fu, Space and Place-The Perspective of Experience. Minneapolis: The University of Minnesota Press, 1977. 
